\title{
The Parallels between Aetiology and Prophecy in Ancient Literature
}

\author{
Hindsight as Foresight Makes Sense
}

Jacqueline Klooster

Introduction: Hindsight as Foresight ${ }^{1}$

As Annette Harder shows in her contribution to this volume, aetiological stories are often used to anchor innovations in the present: "Sometimes we see that a new or future institution in the present is linked to an aetiological story from the past and presented as sanctioned by these events, as if it were a continuation of something that had been predicted a long time ago or had in some way been there all the time", as she phrases it. This can take the form of so-called ex eventu prophecies by a deus ex machina in tragedy, as Harder illustrates with examples from Euripidean tragedy. Both in the Ion (1581-1588) and in the Supplices (1191-1195) the goddess Athena enters the stage near the end and prophesies a future that is meant to forecast the present of the Athenian audience watching the tragedy. Later, Hellenistic poets take over this poetical device and use it for their own purposes, but a central function of such passages remains the embedding of some kind of ideological claim (possibly of an innovative kind, as Harder shows) by means of an authoritative speaker represented as prophesying with foresight out of the past.

W.H. Auden termed this procedure 'hindsight as foresight' in his poem Secondary Epic (1959), ${ }^{2}$ in which he criticizes its use as found in Vergil's Aeneid (in particular in the scene of the manufacturing of Aeneas' shield in book 8 and in the prophecies of Anchises in the underworld in book 6):

\footnotetext{
1 Anchoring Innovation is the Gravitation Grant research agenda of the Dutch National Research School in Classical Studies, OIKOS. It is financially supported by the Dutch ministry of Education, Culture and Science (NWO project number 024.003.012). For more information about the research programme and its results, see the website www.anchoringinnovation.nl. This chapter was written with the generous funding of this project. For the concept of 'anchoring innovation' see Sluiter 2017. All translations, unless otherwise stated, are by Jacqueline Klooster.

2 Published in Homage to Clio, Auden, 1960.
} 
No, Virgil, no:

Not even the first of the Romans can learn

His Roman history in the future tense,

Not even to serve your political turn;

Hindsight as foresight makes no sense.

The use of aetiology as prophecy is here being interpreted as the result of a 'political turn', and Auden states that it "makes no sense" to have the present guaranteed by gods in the past. He shows up the less persuasive sides of the procedure by pointing out, for instance, that history doesn't simply stop at the moment Vergil and Augustus would have liked it to stop:

What cause could he show why he [Vulcanus] didn't foresee The future beyond 31 B.c.?

Apart from this, the rhetoric of a god-given, providential rule is inherently morally corrupt, so Auden implies, since it can so easily be abused, for instance by

Some blond princeling whom loot had inclined

To believe that Providence had assigned

To blonds the task of improving mankind.

Of course, Auden has a point: to people who no longer believe in superhuman entities such as the Olympian gods, or an overarching Providence that steers world history, it seems crudely manipulative to stage divine guarantors of present glory in fictions about the far past. As a rhetorical strategy it lacks subtlety, to say the least, and we would no longer buy into it.

In this chapter, however, I would like to take a step back, away from the modern point of view and from the functional, rhetorical approach, and rather ask whether we can identify the structural characteristics that link prophecy (both actual and ex eventu) and aetiology. Is it possible that precisely these structural similarities caused their frequent coupling in ancient literature? In particular I wish to address the issue of how the form and style of aetiological narratives and prophecies provoked similar interpretive responses in audiences. ${ }^{3}$

I start by addressing the question why aetiology and prophecy seemingly 'belong together' in the ancient mind. In order to do so, I will look into the structure of aetiology and prophecy as narrative modes, or Denkformen. In

3 The similarity between the interpretation of oracles and that of poetry has been put on the scholarly agenda most influentially by Struck 2004, 162-204. 
particular I will ask: what do these narrative forms aim at, and how do they reach their goal? This involves a look at ancient divinatory practices. Secondly, following Struck, I will argue that both prophecy and aetiology are related to allegorical speech in that they both, in their different ways, proceed by providing a symbolic representation of 'truth'. This may help explain why the two often occur together.

What is aetiology? Aetiological stories usually work by explaining, in a story situated in the (far) past, how something the reader can observe in his or her contemporary world, has come into being. The explananda can for instance take the form of religious rituals, names of cities, remarkable shapes in the landscape, or the names of constellations. Often such stories are marked by 'and since that day', 'and until this very day', or similar phrases, to provide a connection between the far past and the present of the author and his audience; examples of where we can find such stories have been mentioned in the introduction to this volume.

So how does aetiological narrative relate to prophecy? Let me first define that by prophecy I mean both the art of the seer (manteia) and the act of declaring the will of the gods (propheteia), categories that may overlap to some extent. ${ }^{4}$ The umbrella concept of 'divination' under which these forms of prophecy fell was in antiquity divided into inductive and intuitive divination. ${ }^{5}$ The first type is based on the interpretation of signs (e.g. the flight and behavior of birds) to get access to the will of the gods. The second type occurs under direct inspiration of a divinity, and can be either spontaneous or invoked through ritual acts; it results in prophetic utterances or dreams. Both forms of prophecy may relate to either the past of the future, and most often they concern the relation between both.

Whenever a seer concentrates on the past, this usually means (s)he is trying to discover whether the will of the gods has at some point been crossed by humans, which has led to an unwanted situation in the present. When this human failure in respect regarding the divine world (through unlawful acts, pollution, lack of sacrifice vel sim.) has been discovered, the seer can then

4 For a definition of prophecy and divination in Greek antiquity, see: Köckert et al. 2006 (prophecy); Maul et al. 2006 (divination). For a comparative approach, see also Beerden 2013.

5 Cicero respectively calls them genus artificiosum and genus naturale, Div. 2.26-27; cf. Div. 1.11; 1.34 . 
prophesy about what needs to be done in the present/future to redress the wrong and appease the gods - if that is still possible. We can think of the opening of the Iliad, where Calchas is called upon to explain why the Greek army is being struck with the plague, and what can be done to remedy it. In the plot of Sophocles' Oedipus Tyrannus where a similar epidemic is the result of Oedipus' crimes, only the penitence of the unwitting parricide and incestuous husband will lift the plague from Thebes.

Literary renderings of intuitive prophecy, such as the prophetic outburst of Cassandra in Aeschylus' Agamemnon (1072-1330), likewise often connect events from the past with what will happen in the future. Thus, according to Cassandra, the inherited curse of the Atridae, caused by the slaying of Thyestes' children by Atreus, will lead to the death of Cassandra and Agamemnon by Clytemnestra's doing in the play itself $\left(A .1215^{-1240}\right)$, and beyond to Clytemnestra's murder by Orestes $(A .1280-1285$, referring to the events portrayed in Choephoroi). It may be noted that practically all prophecies to be found in Greek literature are prophecies that have been pronounced in the (mythical) past, and for the most part they therefore refer to things that have already happened at the time the audience hears about them as a prophecy. ${ }^{6}$

Based on the above definitions of aetiology and prophecy, let us take a first look at the possible similarities and parallels between the two. Taking them at face value, we could say that both aetiology and prophecy center on the discovery and expression of knowledge that is not readily available to all. A distinctive feature is the strong causal link between the past and the present or future - there is no place for 'chance' in the sense of 'unmotivated events' in this worldview. It is of course much easier to obtain knowledge about what has happened in the recent past or is still going on in the present than it is to find out what happened in the far past or what will happen in the future. But it is equally possible to possess only partial knowledge of the present or the recent past, i.e., a person can only see certain aspects of his or her present situation, while others may for some reason remain hidden from view (we may think again of the unfortunate Oedipus, as blind to his present state as he is to his past). Anyone wishing to obtain knowledge about the unknown territories of the past, the present or the future, will try to get at it by way of an authority in possession of this knowledge. In ancient Greek poetry - and presumably also in daily life - the ultimate authority in these fields would be a divinity, and his or her mouthpieces among humankind, that is to say, anyone who could claim

6 The past they refer to is either the far past or a more recent past; although see Annette Harder's contribution for some examples of literary prophecies that seem to point forward to the actual present/future of the audience of the poem in question. 
to stand in direct contact with the divine: seers, prophets, the Pythia and other tellers of fortune.

In this worldview, past, present and future are related to each other causally in a closed system with hardly any room for chance events. Nevertheless, this unfailing causality is not always easy to see or understand. This explains why prophets are so often disbelieved or misunderstood (think of Tiresias in the Oedipus Tyrannus, or again, Cassandra in the Agamemnon). Nevertheless, the basic belief underpinning Greek divination is that anyone with the power to oversee all the causal links between events is theoretically in possession of a universal knowledge of everything that has happened, is happening, or will in future times happen in the heavens and on the earth. This indeed, is exactly the way the knowledge of the bird seer Calchas is characterized in Iliad 1.69-70:

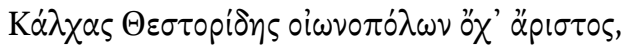

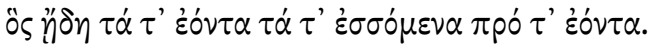

Calchas, the Son of Thestor, the best of the bird seers, who knew the present, the future and the past.

As is widely recognized, this sounds similar to the function of the poet in Hesiod's description of his area of expertise after initiation by the Muses $(\text { Th. } 31-32)^{7}$

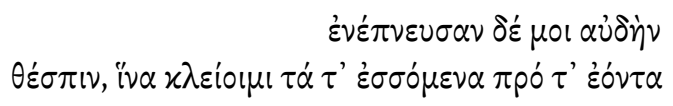

And they breathed into me a divine voice, that I might sing of the future and the past ...

This brings us to the issue of the structural similarity (in archaic Greek thought at least) of the seer and the poet: both stand in direct contact with the gods (in the cases of Calchas and Hesiod these are respectively Apollo and the Muses). These gods thus guaranteed their revelations about the past and/or the future, or rather, in many cases, the causal relation between past, present and future.

7 West 1966, ad Th. 32 writes: "In the absence of written records, the ability to see into the distant past is no less marvellous than the ability to see into the future, and there is no reason for a sharp distinction between the two. Neither is possible without some form of divine revelation, for only the gods have the necessary first-hand knowledge." The locus classicus is Hom. Il. 2.484-486, with the remarks of e.g. Murray 1981 and De Jong 1987, 51. 
How does this link back to aetiology? In aetiological narratives the causal link between a state of affairs obtaining in the present and a forgotten past origin is revealed (again). The fiction of aetiological narratives is thus that the causal connection between the moment of origins and the present has always existed, but has become obscure and forgotten by the passing of time. The poet, with help from the Muses or other gods of poetry, may obtain knowledge of this past, and reveal the lost links of causality, and thus instruct and enlighten the reader. ${ }^{8}$

Returning to the issue of a possible structural parallelism between aetiology and prophecy we can now recognize that this very parallelism is, in a way, both the force and the weakness of both. Both forms of narrative claim to present some kind of revelation: either of a (still) hidden knowledge of the future or of a lost knowledge about the past. This naturally entails that in both cases doubts as to the correctness of the truth claims about future or past events and/or the reconstruction of causality may arise. This, in turn, explains why both aetiology and prophecy try to claim authority for their narrator (poet or prophet) or the informant of this narrator (usually a god) as a truth guarantee. Of course, this can in both cases lead to challenges as to the trustworthiness of the narrator. As noted, prophets and poets regularly receive the accusation that their stories are not truthful. Proverbial is Cassandra's myth, as found for instance in the reference to the disbelief she has formerly encountered (A.1212). But we can also think of the way Oedipus (with great dramatic irony) insults Tiresias as 'blind in all senses' in Sophocles (OT 370). If we look at poets, we will see that the way Hesiod seems to present his Muses as potentially untruthful (Th. 27-28) might even fit this scheme. ${ }^{9}$ Even more broadly speaking, the early criticism of Homer and Hesiod by rationalists like Xenophanes and Herodotus may also serve as an example ${ }^{10}$ - not to mention Plato's criticism of the truth claims of the poets. ${ }^{11}$

8 Intriguing reflections on how information about the past reaches the narrator through the Muses (in a specifically aetiological narrative) is present in the Muse invocations of Apollonius Rhodius, $1.18-22$; $3.1-4 ; 4.1-5 ; 4.55^{2-557}$; 4.1318-1388. See on this: Gonzalez 200o; Cuypers 2004; Morrison 2007, 271-311; Klooster 2011, 216-225. Of course, Callimachus' Muse invocations also explicitly address this issue. See Harder 2012 on this in the appropriate places.

$9 \quad$ There is a large bibliography on the passage: cf. e.g. Verdenius 1972; Stroh 1976; Pucci 1977; Thalmann 1984, 146-149; Nagy 1990, 44-47; Stoddard 2004; Tsagalis 2006.

10 For the early reactions to the truth claims of ancient epic, see the fragments conveniently gathered in Lanata 1963 .

11 For Plato's criticism of Homer, see e.g. Murray 1996. 
So far, I have concentrated on structural similarities between aetiology and prophecy as ways of thinking about the connections between the past, the present and the future. But for my last point I would like to take another look at the way the explanatory aims of aetiology have been evaluated in modern scholarship. In the past, scholars have often claimed that aetiological thinking represented an early form of scientific thought - a naïve way of primitive mankind to explain how the world came into being, and how it turned out the way that they could see around them every day. ${ }^{12}$ Nowadays, hardly anyone believes that this is a sufficient description of the actual goals of aetiological narratives. Aetiological myths often clearly do not aim at the acquisition or presentation of exact and accurate knowledge of the past in the way that modern scientific (or even historical) enquiry does. ${ }^{13}$ The fact that an ironic poet like Callimachus claims that this knowledge is exactly what aetiology is really about, should tell us enough. ${ }^{14}$

Johanna Loehr distinguishes between 'Wissensbedürfnis' and 'Lebensbedürfnis' in this context. ${ }^{15}$ In her view, an aition is hardly ever told to provide factual, exact knowledge about the past. Rather, the aim of such aitia is to function as moral injunctions, ethical standards or examples for the present by the telling of symbolic, figurative stories about the past. Moreover, the fact that events in such stories are often situated in a primordial age, as she suggests, ipso facto lends them a certain authority.

This is not, however, the authority of historical, factual truth. Indeed, the stories told in ancient aetiological myths were in antiquity already understood to contain moral, symbolic truths hidden under the surface, rather than actual or factual truths: they needed to be decoded by the audience. This can be illustrated for instance by the well-known aetiological Myth of the Four Races as told by Hesiod in the Works and Days (106-201), details of which are interpreted by Socrates in Plato's Cratylus (398b-c). The Myth of the Four Races, in which the Hesiodean narrator tells of the moral decline of humanity by speaking of a Golden, Silver, Bronze and Iron Race, is meant to explain the human

\footnotetext{
12 Gunkel 19o1, xi-xii.

13 Loehr 1996, 1-38, esp. 34-38.

14 For Callimachus' playfulness, see the still valuable essay of Snell 1975[1946]. His thirst for (utterly irrelevant and obscure) knowledge is expressed in Aetia frgg. 3.1-2; 7c.1-3; 31c+ 31g; 43b.1-6; 178.21 Harder. On the "desire ... to bring origins to light" as the 'plot' of the Aetia, see Sistakou 2019. For the fact that this aetiological knowledge is at heart predominantly irrelevant, see Asper 2013.

15 Loehr 1996, 34-38.
} 
condition, in particular the hardships experienced by current humankind. But already in the classical age, Hesiod's use of metals to refer to races was seen as metaphorical, and this apparently also raised the question how the other details of the myth were to be understood. In this vein, Socrates addresses the question why the Golden Race is called 'golden', and connects this with the fact that earlier (at Hes. Op. 122) the members of this race are said to have become $\delta \alpha i \mu o v \varepsilon s$. This, he explains, merely means that the Golden Race was a race of

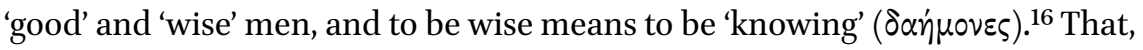
Socrates playfully asserts, is the actual meaning of the passage; so we should not understand Hesiod in terms of 'real' golden men, or 'real' daimones; the poet speaks figuratively.

Interestingly enough, this kind of interpretation was not only applied to poetic texts, but also to the explanation of actual aetiological lore, in particular questions of ritual practice, which of course is inherently interpretable as 'symbolic'. This can for instance be shown by Plutarch's Quaestiones Romanae (on which see in more detail Meeusen, in this volume). In this first century prose work, the author discusses the reasons for 113 ancient Roman ritual customs, whose rationale has seemingly become unclear with time. The entries mostly have the following structure: they open with the question 'why is it that' ( $\Delta i \dot{\alpha} \tau i$...;), after which a number of possible explanations are provided. Intriguingly, these explanations can range from 'historical' (the custom originated because person/situation A initiated it) and 'mythical' (the custom is related to mythical hero/event B), to socio-cultural/ethical/religious (the custom was the result of Roman character trait $\mathrm{C} /$ ethical-religious consideration D) to actually symbolical or allegorical (the custom symbolizes some deeper meaning E not immediately apparent). ${ }^{17}$ The following passage may serve as an example (Moralia $279 \mathrm{~d}-\mathrm{e}$ ):

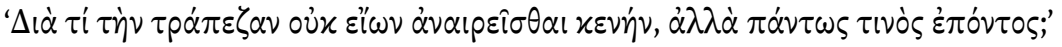

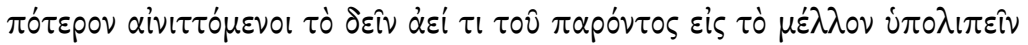

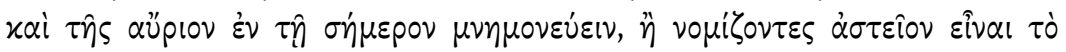

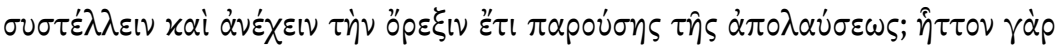

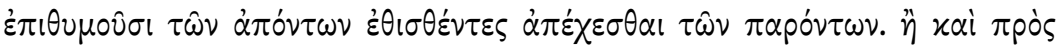

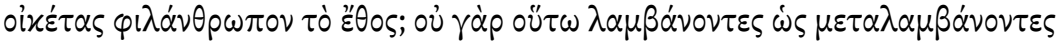

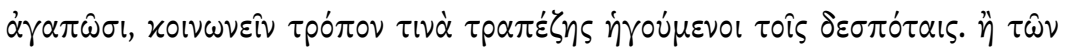

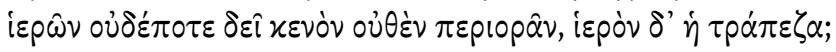

16 See on this passage, and similar interpretations, Struck 2004, 35.

17 See on the Quaestiones Romanae e.g. Payen 2013, and further Michiel Meeusen's chapter in this volume, with bibliography. 
Why did they not allow the table to be taken away empty, but insisted that something should be upon it?

Was it (1) because they were symbolizing ( $\alpha i v \iota \tau \tau o ́ \mu \varepsilon v o l)$ the necessity of ever allowing some part of the present provision to remain over for the future, and today to be mindful of tomorrow? Or (2) did they think it polite to repress and restrain the appetite while the means of enjoyment was still at hand? For persons who have accustomed themselves to refrain from what they have are less likely to crave for what they have not. Or (3) does the custom also (xai) show a kindly feeling towards the servants? For they are not so well satisfied with taking as with partaking, since they believe that they thus in some manner share the table with their masters. Or (4) should no sacred thing be suffered to be empty, and the table is a sacred thing?

transl. F.C. BАВВIтT

Without wishing to enter into the order of the answers given here, or their precise interpretation, I would like to point out how interesting in particular the first exegetic strategy is, hinging as it does on the symbolic meaning of the actual ritual act. As this shows, how the custom originated is clearly less important than what it may (still) convey as a lesson today, in this interpretation: that one should ever be mindful of the future. This explanation represents a Lebensbedürfnis, rather than a Wissensbedürfnis. ${ }^{18}$

This assessment of aetiology as serving a Lebensbedürfnis rather than a Wissensbedürfnis also brings me to my last point. That aetiological narratives explaining certain situations in the present (often with future implications) were usually not expected to be factually, literally true, but rather morally and symbolically so, actually provides another parallel with forms of prophecy, such as the oracle and the intuitive prophecy. ${ }^{19}$ Oracles and intuitive speeches by inspired prophets are proverbially ambiguous or obscure, e.g. through their use of metaphor, allegory or otherwise symbolic circumscriptions of the past

18 Cf. also Quaestiones Romanae 18, 'Why did they offer a tithe to Heracles?' (Moralia $276 \mathrm{e}-\mathrm{f}$ ), in which a similarly 'symbolic' explanation with ethical overtones is given next to two alternative mythical/historical ones.

19 The idea that the interpretational strategies required by prophecy influenced allegorical readings of poetry is discussed by Struck 2004, 165-182. 
and the future. ${ }^{20}$ In that sense they too are not 'literally' true; rather, through their obscurity, they invite the effort of an interpreter to get at the deeper meaning (the hyponoia) hidden by ambiguity or in the images used, in order to understand the divine injunction couched in the riddles; they, like aetiological myths about the past, need decoding. ${ }^{21}$

We can think of two famous examples from Herodotus (but countless more from other sources could of course be provided). The oracle received by Croesus in 1.53, to the effect that he would 'destroy a great empire if he crossed the Halys', and the oracle received by the Athenians in 7.141, the relevant part of which says:

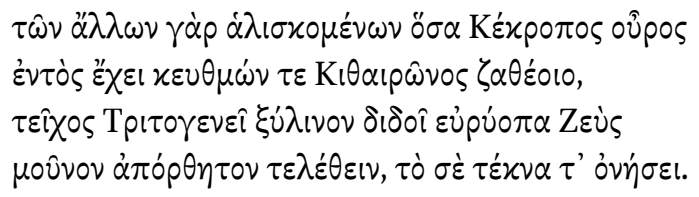

When all the other things shall have been taken, as much as the limits of Cecrops holds within it, and as much as divine Cithaeron encompasses, then far-seeing Zeus will give a wooden wall to Tritogeneia to remain unscathed alone - it will help you and your children. (my translation)

In both cases, Herodotus underlines the efforts needed to interpret correctly the obscure oracles. Croesus famously fails in this respect, and, mistaking the meaning of the ambiguous oracle, becomes the cause of his own defeat, as the Pythia later explains. ${ }^{22}$ In the midst of heated discussions about its meaning (7.142) Themistocles interprets the oracle about the wooden walls of Athens

20 On the enigmatic quality of oracles, see Plutarch (Moralia 407a-b; 409c-d); Clemens of Alexandria Strom. 5.4.21; Struck 2004, 170-180. On intentional obscurity and its uses in ancient texts, see Sluiter 2016.

21 A beautiful illustration of the parallel felt between the interpretation of poetry and divination is given in Cicero Div. 1.34. On the topic in general, see Struck 2004, 167-170. Sluiter 2016, 44 observes: "intentional obscurity may be used as a pedagogic stimulus to encourage the reader or student to look further and deeper and make a greater effort".

22 In Hdt. 1.91.4 the Pythia says: 'But as to the oracle that was given to him, Croesus is wrong to complain concerning it. For Loxias declared to him that if he led an army against the Persians, he would destroy a great empire. Therefore he ought, if he had wanted to plan well, to have sent and asked whether the god spoke of Croesus' or of Cyrus' empire. But he did not understand what was spoken, or make further inquiry: for which now let him blame himself.' Translation A.D. Godley. As she further explains (1.91.5), Croesus has also misunderstood the oracle concerning Cyrus (1.55.2) to the effect that his kingship would 
'correctly', as the event proves, understanding these 'walls' metaphorically to stand for ship hulls. His ingenuity garners him great success: the Athenians, who before the proposal of the correct solution had seemed doomed, are saved and emerge victorious from the battle of Salamis. ${ }^{23}$ These are merely two of the most striking and well-known stories to illustrate the structural ambiguity of oracles and the way this aspect gets thematised by authors concerned with issues of interpretations of such texts.

\section{A Case Study: Thera and the Colonization of Libya in Apollonius, Pindar and Herodotus}

I would like to end with the consideration of one particularly intriguing case of aetiology as prophecy (or vice versa) as found in Apollonius' Argonautica book 4.1729-1764 (also discussed by Harder), because, as I suspect, it deliberately plays on and combines the figurative nature of both aetiological stories and prophecy.

The Argonaut Euphemus has received a clod of earth in Libya from the god Triton. He dreams that the clod grows into a diminutive girl, which he suckles at his breast, after which he has sex with her. Afterwards, still in his dream, he weeps, feeling guilty as though he has committed incest with his daughter. But the girl consoles him (A.R. 4.1741-1745):

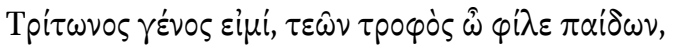

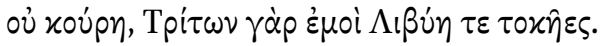

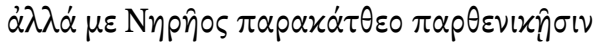

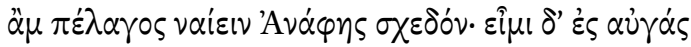

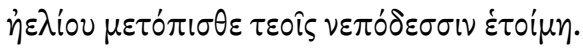

I am Triton's child, my friend, the nurse of your children, not your daughter, for Triton and Libya are my parents. Entrust me to the daughters of

not remain safe if a mule should rule over the Persians. The metaphorical 'mule' is Cyrus, who is part Persian, part Median.

23 Although others had understood the 'wooden walls' to be ships hulls, Themistocles argues that this must be correct by focusing on the address to Salamis as 'Holy Salamis' ( $\bar{\omega} \theta$ हin $\Sigma \alpha \lambda \alpha \mu$ i $)$ ) in the oracle's last line but one ('Holy Salamis, thou shalt destroy the offspring of women'). He correctly saw that this signified that the victims (in a naval battle at Salamis) would be the Persians, not the Greeks (7.143.1). 
Nereus to live in the sea near Anaphe, and I shall later emerge into the sunlight, on hand for your descendants.

transl. W.H. RACE

Later, Jason explains the explanation the girl has given to Euphemus: the latter has to throw the Libyan clod into the sea, after which it will turn into an island (4.1749-1754). The narrator confirms in a prolepsis that this is what actually happened, after which Greek colonizers reached Libya via the island, first called Calliste, later Thera $\left(4 \cdot 1755^{-1764}\right)$. The aim of this episode seemingly is to provide a justification for Greek presence in Libya. ${ }^{24}$

Two features of this episode catch the eye: the complex layering of symbolism, and the related emphasis on interpretation. The clod is initially a piece of earth, symbolically given as a guest gift by the god Triton (4.1551-1555). Next, in the prophetic dream, the clod manifests itself as a girl, daughter of Triton and Libya, nurse of the children of Euphemus. Finally, Jason explains that the clod will metamorphose into an island. The narrator confirms this, and thus provides the interpretation that the clod will turn out to be both literally an island and figuratively speaking the nurse of Euphemus' descendants, born from the Lemnian women.

Hypothetically, it is entirely possible that a story like this, about the island Thera and the descendants of Euphemus would either be told purely in terms of a metamorphosis (from anthropomorphous nymph into actual island), or only in terms of literal 'clods of earth' turning into islands. We can for instance think of the parallel story of the nymph Asterie who, after becoming a star, turns into the island Delos. ${ }^{25}$ On the other hand Pindar tells the story of the birth of the island Thera purely in terms of the 'clod' about which Medea prophesizes in Pythian 4. The clod is not personified as such, although the

24 See Annette Harder's chapter in this volume. On the clod as embodying the symbolic claim of the Greeks to Cyrene, see Stephens 2003, 178-183; Hunter 2015, 312. On this episode, see Thalmann 2011, 82-87, who stresses the sexual metaphors as signifying colonization. On this topic more in general, see Dougherty 1993. See now also the discussion in Klooster 2019, 57-75, and Morrison 2020, 107-111, 138-140. The latter rather points to the gap existing between the mythical aetiology given here and the 'present' of the Ptolemaic readers in 3 rd century Alexandria, which is underlined by the leaving out of the result of the colonization story: the story ends before the founding of Cyrene. In his interpretation, this is deliberate, and aims at bringing to light the discontinuities between mythical past and the present day.

25 The story is told in the h. Ap. and Callimachus' Hymn to Delos. On the strangeness of the ambiguous nature of Delos there (apparently somehow pictured as a girl, a star (?) and an island at the same time), see Klooster 2012. 
metaphorical language used to describe its purpose does point in the direction of sexual intercourse. ${ }^{26}$

An intriguing parallel story in which a girl emerging from the sea becomes the mother of the founders of Libyan Cyrene is found in Herodotus (4.154-155). This episode, apparently an alternative to the more common Theraean story about the colonization of Libya, ${ }^{27}$ in fact features a girl, named Phronime, who is thrown into the sea on the orders of her father Etearchus (on the suggestion of the latter's cruel second wife) by a certain Themison, a guest-friend of Etearchus. Themison has been tricked into this crime by a promise, as Herodotus recounts (4.154.4):

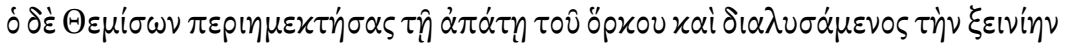

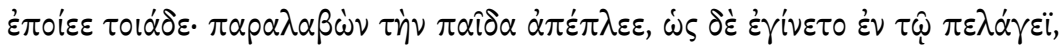

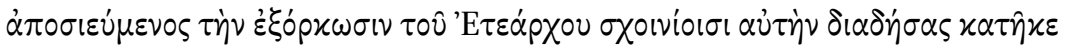

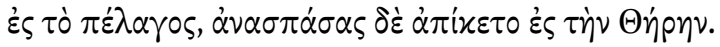

But [he] was very angry at being thus tricked on his oath and renounced his friendship with Etearchus; presently, he took the girl and sailed away, and so as to fulfill the oath that he had sworn to Etearchus, when he was on the high seas he bound her with ropes and let her down into the sea and drew her up again, and presently arrived at Thera.

transl. A.D. GODLEY

Arriving safely on Thera after her sea baptism, Phronime becomes the concubine of a notable Theraean, Polymnestus, who eventually fathers Battus by her, the legendary colonizer of Cyrene (4.155.1). The story reveals some striking parallels with Apollonius' episode, notably that the girl is thrown into the sea but emerges again to become the mother of the Theraean colonizers of Libya. It seems likely that Apollonius took elements from both Pindar (Euphemus and the clod, thrown into the sea, the prophecy, the sexual metaphors of colonization) and Herodotus (the actual girl thrown into the sea who becomes the mother of the Cyrenaean kings) and combined them into the curious prophetic dream-cum-aetiology in his fourth book.

With its surprisingly layered symbolism, the passage seems to acknowledge the metaphorical meaning inherent in both prophetic and aetiological

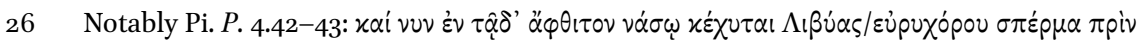
ढ̈pas ('The immortal seed of spacious Libya has been shed upon this island prematurely').

27 Hdt. 4.154.1: 'For the Cyrenaeans tell a wholly different story about Battus, which is this: ...'. I discuss this parallel in more detail in Klooster 2019, 57-75. 
stories and by doing so moreover stages a continuum of interpretive efforts: the Argonauts and the narrator interpret the initial prophetic dream, and the eventual narratees will try to decode the poetic episode with their knowledge of variant stories, both mythical and historical about this Greek past, but the main message they need to take away seems to be: the Greek presence in the Cyrenaica is legitimate, time-honored and divinely sanctioned, whichever way we look at it.

Seen in the context of ancient ideas about prophecy and poetry, hindsight as foresight makes perfect sense, to contradict Auden. Like the future, the past is hard to oversee. Any poet or prophet wishing to speak about it, therefore needs to support his/her claims to knowledge with the authority of a divine perspective, which ideally speaking enables the revelation and interpretation of the causal connections between past, present and future - although of course such prophetic revelations and divine authority can be and often are indeed problematized by poets. ${ }^{28}$ In aetiological contexts, this causal connection generally implies a legitimation of the present status quo, and an injunction about future actions to maintain this status quo. Prophecies mostly focus on the injunction about the future, which is supported by an explanation of how the present came into being. When combined into ex eventu prophecies, they can do both. The trouble with knowledge of the present and the past is that it is hard to obtain, and can apparently only be given in symbolic terms. Both aetiological and prophetic narratives should therefore be taken figuratively rather than literally. Their figurative, often obscure, truth needs interpretation, the uncovering of the actual significance. It is this set of beliefs that has led to the flourishing of aetiological prophecy in many genres in Greek and Latin literature.

\section{Bibliography}

Asper, M. (2013). Minding the Gap. Aetiology and (False) Closure. In: F. Grewing, B. Acosta-Hughes and A. Kirichenko, edd., The Door Ajar. False Closure in Greek and Roman Literature and Art. Heidelberg: Winter, pp. 63-82. Auden, W.H. (196o). Homage to Clio. New York: Random House.

28 See for instance the role of Jupiter in the Aeneid with O'Hara's observations on the inconsistencies in his prophecies (O'Hara 2010). 
Beerden, K. (2013). Worlds Full of Signs. Ancient Greek Divination in Context. Leiden/ Boston: Brill.

Cuypers, M. (2004). Apollonius of Rhodes. In: I. de Jong, R. Nünlist and A. Bowie, edd., Narrators, Narratees and Narratives in Ancient Greek Literature. Leiden/Boston: Brill, pp. 43-62.

Dougherty, C. (1993). The Poetics of Colonization. From City to Text in Archaic Greece. New York/Oxford: Oxford University Press.

Gonzalez, J. (2000). Musai Hypophetores. Apollonius of Rhodes on Inspiration and Interpretation. Harvard Studies in Classical Philology, 100, pp. 268-292.

Gunkel, H. (1910). Genesis übersetzt und erklärt. Göttingen: Vandenhoeck \& Ruprecht. Harder, A. (2012). Callimachus. Aetia, 2 vols. Oxford: Oxford University Press.

Jong, I. de (1987). Narrators and Focalizers. The Presentation of the Story in the Iliad. Amsterdam: Grüner.

Klooster, J. (2011). Poetry as Window and Mirror. Positioning the Poet in Hellenistic Poetry. Leiden/Boston: Brill.

Klooster, J. (2012). Visualizing the Impossible. The Wandering Landscape in the Delos Hymn of Callimachus. Aitia. Regards sur la culture hellénistique au XXIe siècle, 2. Available at: http://aitia.revues.org/420 [Accessed 17 January 2019].

Klooster, J. (2019). The Thera Episode in Argonautica IV reconsidered in light of the poetic interaction between Apollonius and Callimachus. Aevum Antiquum, N.S. 19, pp. $57-75$.

Köckert, M. et al. (2006). Prophets. In: H. Cancik and H. Schneider, edd., Brill's New Pauly Online. Available at: http://dx.doi.org.proxy-ub.rug.nl/10.1163/1574-9347_bnp_ e1010570 [Accessed 15 January 2018].

Lanata, G. (1963). Poetica pre-platonica. Testimonianze e frammenti. Florence: La Nuova Italia.

Loehr, J. (1996). Ovids Mehrfacherklärungen in der Tradition aitiologischen Dichtens. Stuttgart/Leipzig: Teubner.

Maul, S. et al. (2006). Divination. In: H. Cancik and H. Schneider, edd., Brill's New Pauly Online. Available at: http://dx.doi.org.ezproxy.leidenuniv.nl:2048/10.1163/1574-9347_ bnp_e32163o [Accessed 17 January 2019].

Morrison, A. (2007). The Narrator in Archaic Greek and Hellenistic Poetry. Cambridge: Cambridge University Press.

Morrison, A. (2020). Apollonius Rhodius, Herodotus and Historiography. Cambridge: Cambridge University Press.

Murray, P. (1981). Poetic Inspiration in Early Greece. Journal of Hellenic Studies, 101, pp. $87-100$.

Murray, P. (1996). Plato on Poetry. Ion, Republic 376e-398b9, Republic 595-6o8bro. Cambridge: Cambridge University Press. 
Nagy, G. (1990). Greek Mythology and Poetics. Ithaca, NY: Cornell University Press.

O'Hara, J. (2010). Inconsistency in Roman Epic. Studies in Catullus, Lucretius, Vergil, Ovid and Lucan. Cambridge: Cambridge University Press.

Payen, P. (2013). Plutarch the Antiquarian. In: M. Beck, ed., A Companion to Plutarch. Malden/Oxford: Wiley-Blackwell, pp. 235-248.

Pucci, P. (1977). Hesiod and the Language of Poetry. Baltimore/London: John Hopkins University Press.

Sistakou, E. (2019). De-Narrating the Narratable in the Aetia. A Post-Modern Take on Callimachean Aesthetics. In: A. Harder, J. Klooster, R. Regtuit and G. Wakker, edd., Callimachus Revisited. New Perspectives in Callimachean Scholarship. Leuven: Peeters, pp. 329-35o.

Sluiter, I. (2016). Obscurity. In: A. Grafton and G. Most, edd., Canonical Texts and Scholarly Practices. A Global Comparative Approach. Cambridge: Cambridge University Press, pp. 34-51.

Sluiter, I. (2017). Anchoring Innovation. A Classical Research Agenda. European Review, $25(1)$, pp. $20-38$.

Snell, B. (1975 [1946]). Über das Spielerische bei Kallimachos. In: Die Entdeckung des Geistes. Studien zur Entstehung des europäischen Denkens bei den Griechen. Göttingen: Vandenhoeck \& Ruprecht, pp. 244-256.

Stephens, S. (2003). Seeing Double. Intercultural Politics in Ptolemaic Alexandria. Berkeley: University of California Press.

Stoddard, K. (2004). The Narrative Voice in the Theogony of Hesiod. Leiden/Boston: 2004.

Stroh, W. (1976). Hesiods lügende Musen. In: H. Görgemanns and E.A. Schmidt, edd., Studien zum antiken Epos. Meisenheim am Glan: Hain, pp. 90-97.

Struck, P. (2004). Birth of the Symbol. Ancient Readers at the Limits of their Texts. Princeton/Oxford: Princeton University Press.

Thalmann, W. (1984). Conventions of Form and Thought in Early Greek Epic Poetry. Baltimore/London: John Hopkins University Press.

Thalmann, W. (2011). Apollonius of Rhodes and the Spaces of Hellenism. Oxford/New York: Oxford University Press.

Tsagalis, C. (2006). Poet and Audience. From Homer to Hesiod. In: F. Montanari and A. Rengakos, edd., La poésie épique grecque. Métamorphoses d'un genre littéraire. Vandœuvres/Geneva: Fondation Hardt, pp. 79-130.

Verdenius, W. (1972). Note on the Proem of Hesiod's Theogony. Mnemosyne, 25(3), pp. $225^{-26 o .}$

West, M. (1966). Hesiod. Theogony. Oxford: Clarendon Press. 